\title{
ENSOULING THE BEATIFIC VISION. MOTIVATING THE REFORMED IMPULSE
}

\author{
JOSHUA R. FARRIS, RYAN A. BRANDT* \\ Houston Baptist University, Grand Canyon University
}

\begin{abstract}
The beatific vision is a subject of considerable importance both in the Christian Scriptures and in the history of Christian dogmatics. In it, humans experience and see the perfect immaterial God, which represents the final end for the saints. However, this doctrine has received less attention in the contemporary theological literature, arguably, due in part to the growing trend toward materialism and the sole emphasis on bodily resurrection in Reformed eschatology. As a piece of retrieval by drawing from the Scriptures, Medieval Christianity, and Reformed Christianity, we motivate a case for the Reformed emphasis on the immaterial and intellectual aspects of human personal eschatology and offer some constructive thoughts on how to link it to the contemporary emphasis of the body. We draw a link between the soul and the body in the vision with the help of Christology as reflected in the theology of John Calvin, and, to a greater extent, the theology of both John Owen and Jonathan Edwards.
\end{abstract}

KEY WORDS: beatific vision, substance dualism, Reformed dogmatics, John Owen, Jonathan Edwards

\section{Introduction}

The beatific vision is a subject of considerable importance both in the Christian Scriptures and in the history of Christian dogmatics. It represents the final end for the saints in which they see God. This doctrine held a substantial place in the medieval literature and the Reformed dogmatic literature, yet it receives little attention in the contemporary Reformed literature. In part, this development may be due to the overwhelming emphasis on the physical resurrection of the body over the immortality of the soul. This development may also be due in part to the success of the physical sciences

JOSHUA R. FARRIS (PhD 2015, University of Bristol) is Assistant Professor of Theology at Houston Baptist University and Visiting Fellow at Heythrop College, University of London. Email: jfarris@hbu.edu; RYAN A. BRANDT (PhD 2015, The Southern Baptist Theological Seminary) teaches full time at Grand Canyon University and Grand Canyon Theological Seminary, but also works as Managing Editor for the Journal of Biblical and Theological Studies. Email: ryan.brandt@gcu.edu. 
and its attending philosophical developments of materialist ontology. Reflecting these tendencies, the recent contemporary theological discussions have almost exclusively focused on the body and the physical resurrection as it pertains personal eschatology, both in Reformed constructions and outside of Reformed circles (see Bynum 1995: 1-33, Coakley, 2000: 61-73, Eagleton 1996, Hoekema 1994, Wright 2008). We are convinced, however, that the immaterial emphasis of the vision is justified, yet the relationship between the soul and body as it pertains to human purpose in the vision requires additional development.

The tendency is out of sync with the medieval and Reformed traditions and, we are convinced, revises an important part of it. In an attempt to revive the traditional impulse towards immateriality in the vision, we constructively retrieve from the historical tradition with the use of some contemporary philosophical tools. By immaterial, we refer to that substantial reality that is non-material. In a phenomenological framework, the experience of qualities in the real world point to and presuppose an immaterial substance that is, common sensically, distinct from material substantial reality. The material is characterized by a third-person point of view, is public, and carries with it spatial extension. (Granted one might be an idealist and reject that there is material substantial reality.) We will continue this discussion below as we draw from contemporary philosophy of mind to fill out the Reformed understanding of the soul in the vision, an understanding that deserves further attention since it developed the medieval doctrine of the beatific vision in interesting Christological directions.

This article accordingly has a twofold argument: (1) the Reformed tradition correctly maintained that the beatific vision was fundamentally immaterial, yet (2) this tradition is in need of further development to give proper weight to the final, glorified material existence of the person and its attending Christological aspects. The paper will demonstrate the thesis in four parts. First, it explores the medieval tradition of the vision as immaterial. Second, it describes the related Reformed tendency, which is grounded in two theological principles, namely, God's pure immateriality and humanity as essentially immaterial. By 'essential', we do not mean that human persons do not have an intimate relation with their bodies when they are embodied. We do not intend to convey that the body is unimportant. We only intend to convey that the human person is at the core immaterial, i.e., a soul. If a person loses the body during the intermediate state of existence, yet remains the self-same person, then s/he is essentially a soul. Human persons are either essentially embodied or contingently embodied. For human persons to be essentially embodied would require that they remain embodied at every point in their existence as human persons or it would follow that the person would cease to exist. Human persons do not remain embodied at every 
point in their existence. Therefore, human persons are contingently embodied. Third, it claims that the traditional Reformed tendency is correct and philosophically justified, but, in the final analysis, there is a significant challenge concerning the relationship between an immaterial beatific vision and a material glorified existence (i.e., somatic resurrection). Fourth and finally, we suggest a brief and modest way forward through John Owen and Jonathan Edwards.

\section{Medieval Tradition}

Because the Reformers were working within the context of the medieval construction, it is helpful to note the propensity towards the immaterial and intellectual elements in both Peter Lombard and Thomas Aquinas. First, Peter Lombard prioritizes the immaterial over the material in his discussion of the beatific vision. While Peter places his discussion of the beatific vision after the resurrection and judgment, it is not entirely clear what state he imagines the vision taking place. However, the distinctions he examines and the way in which he examines them show that he conceives of the vision primarily in immaterial terms, especially through the assumption that the vision is chiefly intellectual (see Rosemann 2004). He begins by addressing the mansions in heaven and hell, respectively, concluding that 'to have life is to see life, that is, to know God face to face' (Lombard 2010: 266).

The nature of the beatific state is one primarily of soulish, or intellectual, qualities. Indeed, to 'have life is to know you [God]' (Lombard 2010: 266). The standing assumption that the vision is immaterial and intellectual is confirmed as he continues to consider the state of blessedness, which he defines in terms of willing and knowing the good-again, both soulish qualities (Lombard 2010: 267-68). He goes on to discuss the different degrees of knowledge and joy in the beatific state (Lombard 2010: 269-70). Interestingly, a discussion of the body's place in the vision is lacking, except for a reference from Augustine (Lombard 2010: 270). Peter prioritizes the immaterial and intellectual in the beatific vision.

Thomas Aquinas also prioritizes the immaterial and intellectual. Like his predecessor, Peter, Thomas focuses on the vision in terms of the intellect (Aquinas 2012: Suppl. IIIae. 93, a. 1-3). While he discusses the glorified body's role in the vision (Aquinas 2012: Suppl. IIIae. 93, a. 2), he does not grant the body particular weight in the discussion: 'The intellect can perceive spiritual things, whereas the eyes of the body cannot: wherefore the intellect will be able to know the Divine essence united to it, but the eyes of the body will not' (Aquinas 2012: Suppl. IIIae. 93, a. 2, ad. 7).

The bodily senses are thus limited in capacity compared to the immaterial intellect in the vision. Thomas also suggests that we actually gaze God in his essence: 'God will be seen in His essence by the saints in heaven' (Aqui- 
nas 2012: Suppl. IIIae. 93, a. 1, s. c., see also Smith 2003: 34, 50-52). Thomas prioritizes the immaterial in the beatific vision.

\section{Reformation Tendency}

Next, and more substantially for this article, we demonstrate that the Reformed tradition, following Peter and Thomas, has prioritized the immaterial and intellectual aspects of the beatific vision. Because we take this Reformed emphasis as sufficiently clear and straightforward, our discussion will be succinct on this point. By considering some of the most significant Reformed theological authorities, e.g., John Calvin, Francis Turretin, and Charles Hodge, we show that such a tendency is almost overwhelmingly represented in the tradition.

First, while John Calvin does not address the beatific vision systematically, the idea appears occasionally throughout his Institutes (Calvin 1960: 1.484-86 and 1.569-71). Calvin's emphasis on the immaterial is most clearly visible when he discusses human anthropology as an image of the divine. Calvin is committed to Plato's understanding of the human constitution, including the supposition that the soul or the mind is more fundamental than the body. He states, 'Now I understand by the term 'soul' an immortal yet created essence, which is his nobler part' (Calvin 1960: 1.184). For Calvin, it is the soul or the mind (henceforth 'soul') and its powers that provides the appropriate connectedness to God in Christ, for the soul has primacy with respect to the image (see Helm 2004: 218-19 and Helm 2010: 218-19).

We can infer from Calvin's link between creation and redemption, concerning the image, that this link carries over into his understanding of the visio dei as he understands it in 2 Corinthians 3:18. How it is that Calvin understands or would understand the role of the body in the beatific vision is a matter worthy of further exploration, but for our purposes here this discussion would take us too far afield. It is important to note that Calvin's Augustinian emphasis on the image as mind or soul endures as a common feature in the Reformed tradition. Turretin especially reflects this closely.

Second, following the enumeration of Thomas Aquinas, Francis Turretin offers the Reformed theologian a more explicit and developed treatment of the beatific vision than what we find in Calvin. He places his discussion of the vision in the context of eternal life. The primary elements of eternal life, he avers, are sight, love, and joy: sight 'contemplates God' and 'perfects the intellect,' love moves toward (and ultimately unites with) God and perfects love, and joy enjoys God and perfects the conscience (Turretin 1997: 3.609). In the context of these three, he describes the vision: the vision 'implies the most perfect and clear knowledge of God and of divine things, such as can belong to the finite creature' (Turretin 1997: 3.610). He contrasts this clear 
and distinct knowledge with the specular and enigmatical knowledge in the present state. On account of God's incorporeal nature, Turretin continues, he 'accordingly cannot fall under a sense of the body because power is not carried beyond its own object' (Turretin 1997: 3.610).

In other words, Turretin explains that God cannot be seen by bodily eyes. Indeed, while the resurrection eyes will 'become spiritual as to qualities, they will not be 'changed into spirits, but remain corporeal' (Turretin 1997: 3.611). Thus, even after the resurrection the bodily eyes cannot gaze God's essence. Once again this is because, for the Reformers, God is immaterial in nature, and thus we are-at least at our core-immaterial in nature. In continuity with Calvin, Turretin understands the human constitution to be fundamentally immaterial (see Turretin 1997: 1.482-88). [For clear evidence along these lines, see $i b i d ., 1: 482-88$. Turretin clearly articulates the soul's priority over the body so that, when the body dies, the soul continues to operate, subsist, and act independently of the body (cf. ibid., 485-86).] The climax of our redemption, while inclusive in some sense of resurrection for Turretin, is the spiritual and thus immaterial vision of God: 'God can be seen of man by a spiritual and internal vision alone' (Turretin 1997: 3.611).

Thus far, there is an open question as to the state in which the vision occurs in Turretin. Is it the disembodied interim state or the final glorified state, which includes the physically resurrected body? While Turretin has not clarified the state in which the vision will take place, he has implicitly shown that the immaterial takes primacy in creation and redemption; thus, there is a seeming tension between the disembodied interim state and the physically resurrected state. A case might even be made that Turretin inconsistently moves from considering a disembodied soulish state and an embodied glorified state (Turretin 1997: 3.609-11). His inconsistency is evident in that after he discusses the vision in the context of soulish qualities (primarily, if not exclusively), he concludes his discussion of the vision by saying, 'Now from this communion with God will arise that wonderful glory with which the saints will be endowed both as to the soul and as to the body. And as to the former, indeed by perfect knowledge and holiness; and as to the latter, by a removal of all misery, pollution and weakness of every kind, arising not only from sin, but also from the condition of animal life which had obtained communication into a state of innocence and incorruption and spirituality' (Turretin 1997: 3.612).

While Turretin clearly prioritizes the immaterial over the material, one wonders how he connects the beatific vision with the final bodily resurrected state. There is an interesting tension here. However, Turretin more likely than not places the discussion of the vision in the context of the disembodied state because of his close alignment with Thomas. He clarifies this 
position as he suggests, as cited before, 'God can be seen of man by a spiritual and internal vision alone' (Turretin 1997: 3.611). We can gaze this now in the 'specular knowledge of faith', but we will gaze it later by an 'intuitive and far more perfect beatific vision' (Turretin 1997: 3.611). In particular, Turretin clarifies, it is the soul itself that is gazing God in this beatific state: 'But whether the soul will immediately see the very essence of God or only some reflection of it (apaugasma), rather the brightness and glory suitable to the other life, because the Scripture does not disclose it to us, so neither should we rashly define anything concerning it' (Turretin 1997: 3.611).

He thus seems to be placing the beatific vision in the context of the disembodied state, which is not to say that the soul will cease in the vision once becoming re-embodied but that it will be the soul alone that sees God. He also uses several adjectives to explain the nature of the vision that prioritize the immaterial qualities: mental, intellectual, internal, supernatural, intuitive, beatific, adequate, and comprehensive (Turretin 1997: 3.610-11). Afterwards, he moves to consider the transformation of the human soul in consequence to the vision (Turretin 1997: 3.611-13). His clear emphasis is on the immaterial and intellectual elements.

Third, the famous 19th century Reformed theologian, Charles Hodge, continues the tradition regarding the vision, also showing an impulse towards the immaterial. While he places the discussion after the final bodily resurrection, it lends clear priority to the soul in the vision. He begins by noting that the beatific vision is inconceivable (Hodge 2003: 3:860), but then he states eight elements that we can know about the vision. In particular, he notes, 'This vision is beatific. It beatifies. It transforms the soul into the divine image; transfusing into it the divine life, so that it is filled with the fullness of God' (Hodge 2003: 3:860). It is telling that he directs the beatific elements towards the soul, not the body. Perhaps he is envisioning the beatific vision in the context of the disembodied state, or, more likely, he suggests that the vision, while taking place in the resurrected bodily state, primarily impacts the soul. Either way, the lack of reference to the body is certainly noted.

He also suggests that the vision consists of 'the indefinite enlargement of all [the saints] faculties' and the 'constant increase in knowledge and in the useful exercise of all their powers' (Hodge 2003: 3:860, 861). He does not clarify whether this involves bodily or soulish functions, though his use of 'all' suggests both. Hodge then continues to note other aspects of the vision in terms of perfected love, happiness, holiness, fellowship, goodness, and blessedness (Hodge 2003: 3:860-61). While the tendency towards the soul might be less noticeable than, say, Turretin, Hodge continues the same trajectory as before by prioritizing the soul over the body in his discussion of the vision. 
Fourth, following the tradition before him, Jonathan Edwards unsurprisingly also places the emphasis and centrality on the immaterial in his understanding of the beatific vision (Edwards 1957-2006: 8.723-24). Edwards is explicit that it is not a sight of the eyes but of the soul, and the intellect. This is unsurprising in Edwards given the fact that he upholds that God and humans are essentially immaterial in nature, even if humans are normally embodied. For Edwards, the beatific vision is that which makes humans ultimately happy, which is primarily an immaterial state of being (Edwards 1957-2006: 13.490).

For example, in one place Edwards highlights the act of seeing God for who he is without mention of Christ or the body, by isolating the soul as the object of transformation (Edwards 1957-2006: 10.324). In another place, he associates the vision closely with contemplation-hence an intellectual, emotive, and appetitive activity as seeing God (Edwards 1957-2006: 8.94; cf. 8.534). In several places in the Ethical Writings, Edwards seems to follow Aquinas in his understanding of the vision in the context of the disembodied state-hence an immaterial state (Edwards 1957-2006: 8.720-25).

Edwards describes the general nature of the beatific vision as 'immaterial' and 'intellectual' precisely because the highest part of the human is such; furthermore, God is immaterial in nature and must be encountered not with bodily eyes but with the soul (Edwards 1957-2006: 8.720-25). In other words, Edwards suggests that the vision is intellectual: a seeing with the eyes of the soul. This must-needs-be, for God is spirit and cannot be gazed by physical eyes. While saying this, we do not want to leave the reader with the impression that these selections are all that Edwards mentions about the beatific vision. In fact, we believe that Edwards has much to say that deserves additional constructive attention in the literature. We will briefly explore these constructive elements at the end of this article.

In summary, the Reformed tradition prioritizes the immaterial and intellectual elements of the vision more than the material and bodily elements. This is not to say that the material elements were ignored; rather, it is only to say they were not explicitly and fully articulated in the context of the discussions of the beatific vision.

\section{The Immaterial and Reformation Theology}

With the Reformed tradition's inclination toward the immaterial with respect to the beatific vision (seen most clearly in Turretin) as the end or purpose of humanity, it is curious that the contemporary literature leans in the alternative direction, namely, toward the material, the bodily (at times to the exclusion of the immaterial), and final state of afterlife-i.e., the physical resurrection of the body. Arguably, both impulses resonate with the scriptural portrayal of humanity's end. We are convinced, however, that while 
the Reformed theological developments are in tension with this contemporary literature as represented in the Scriptural teaching of humanities purpose in resurrection and vision, the impulse of the tradition is justified.

We have shown above that the Reformed tradition highlights the immaterial nature of beatific vision based on the fact that God is immaterial and humans are essentially immaterial. Paradigmatically, persons seem to be in a category of their own as distinct from things and their operations in the world around us. Common sense would tell us that we have paradigm examples of material things, as mechanistic and spatially extended, in contrast to persons as immaterial things. In keeping with most of the Christian tradition, God is personal and immaterial. The Western and Augustinian tradition bear this assumption about God: God seems to be a consciously thinking individual with freedom, in the minimalist sense, such that the presupposition that God is immaterial and personal are foundational to all theological reflections about God (Farris 2014, Lund 2003: 93, Swinburne 1994: 126-27).

Such a claim is supported by the testimony of Nicene Christianity where God is described as the creator of the world, the 'Maker of heaven and Earth' (Wilhelm 1911). As practitioners of Perfect Being Theology, Reformed theologians understood God to have various characteristics that are not characteristics of material objects. The Athanasian Creed bears this out, as well, when it describes God as being uncreated, immeasurable, and eternal, theologians often take that to mean that God is a pure immaterial being (Sullivan 1907). On this ground, it would seem to yield the notion that, in order to experience God, some interface with him would require immateriality.

The more challenging claim confronting Reformed theology is that human beings are essentially immaterial, that is, they are immaterial at their core. The claim is especially challenging because, while most Christians today regard God as purely immaterial, that is not the case for humans. Some describe humans as a mixture of the immaterial with the material, if not wholly material in nature. In fact, recently there has been a flurry of recent Christian defenses of the claim that humans are wholly material in nature (see Corcoran 2006, Murphy 2006). However, we argue below that humans are not wholly material but rather essentially immaterial at their core; we do so by suggesting that when we experience the world as an object around us, we do so primarily as immaterial beings. The Reformed understanding of the vision as primarily immaterial, then, in our minds, seems justified for the following reasons: (1) our experiences require an immaterial substance and (2) our experiences are primarily mental.

The first reason that justifies the Reformed impulse is based on the fact that our experiences presuppose the first-person perspective, which re- 
quires an immaterial substance. We take it that vision is a kind of experience. Drawing from holistic empiricism or phenomenal conservatism, which claim that our first-person experiences give us some indication or grasp on reality, we argue for the Reformed claim that we are immaterial essentially and that this comes up as a primary feature in our experiences. Phenomenal conservatism is the view that we have knowledge of something based on what seems or appears to be the case in our experiences; thus, how it appears to be for a person carries with it some level of justification. When our faculties are functioning properly, our seemings are justified and reliably give us knowledge. Holistic empiricism, similar to phenomenal conservatism, is the view that we ought to take all of our experiences as trustworthy until proven guilty, so it encompasses more than the narrow empiricism often associated with the modern empiricist tradition (e.g., Francis Bacon, David Hume). Holistic empiricism rests on the assumption of a holistic anthropology, yet our experiences point us to the fact that we are primarily and essentially immaterial (Kwan 2011, Tucker 2013).

This means that humans, while coming into existence with a body, are at their core immaterial beings, otherwise called minds or souls. Whilst it is true to say that bodies are causally necessary in some sense for the soul's functioning, this would not entail the essentiality and constant requirement that the soul function as embodied. Take the following argument to ground the reality that we, humans, are essentially immaterial.

Consider the act of painting a picture of Jesus Christ. While a contemporary painter has never seen Jesus Christ directly, s/he has some idea of what Christ might look like through traditional data on Christ. With this background, s/he begins the imaginative process of conjuring up an image of Jesus. This process of imagination is not the same as a causal registering of Jesus via the eyes, but it is a mental process cognized. The painter has the ability to reflect more deeply and critically on her image. As s/he enters the process of painting, s/he experiences an interactive process between the mind's picture and what s/he sees painted on the canvass. Now, one can comfortably argue that the imaginative process itself is a process that is not ontologically dependent on material processes in the brain or in the central nervous system; rather, it is a process brought into being by the mind itself-requiring first-person consciousness.

For the painter to continue in the process of painting, two fundamental activities must occur. First, the painter must have a first-person consciousness ability. S/he must be able to imagine, yet in the process of imagining $\mathrm{s} /$ he is holding an idea in his or her mind. In fact, s/he is having a thought about the image of Jesus Christ. What is important to note is that it is the person him/herself holding the thought in her mind. No one else owns the thought nor has access to the mental picture of Jesus Christ that the painter 
has. Contrary to the immaterial, the physical is potentially discoverable by agents. The idea that the agent-painter holds in his/her mind is only accessible directly and immediately by the agent him/herself. Second, the painter must have the ability to endure through time. In order to causally bring the painting into being from an original mental image, the painter must be in the process of thinking, reflecting, and discriminating about the paint on the canvass. These are occurrent activities of the mind presupposed in the act of reflection on the painting. Other occurrent activities are present when the painter is moving her limb in the process of putting paint to canvas.

In contrast to what we intuitively believe from common sense to be a material object, the agent-painter exists in and through time as the self-same individual with the capability of self-reflexively thinking and imagining a new reality. Whether it is case that any material object can exist for very long through time, it is fairly clear that we have no positive reason to think that the material object knows that it exists or continues to know that it exists. In fact, it is not clear at all what material object is identical to the agent. Intuitively, the agent and the material object s/he happens to be attached to, or interact with, is distinct from the agent.

This idea leads to the second point: our experiences are essentially and primarily mental (i.e., immaterial) in nature. It is not clear or conceivable that I am a material object, and supposing I were, it is not clear at all what material object I would be identical to. It would not be the parts of the body. Conceivably, I can lose my hands or feet and remain the self-same person without my hands and feet. It seems unlikely that I would be strictly identical to my body for the reasons given above for I am the kind of thing that endures through time as the same individual, but this is not the case for the body. In fact, it seems inconceivable that we would find a material object to adequately satisfy our intuitions of what it means to be me-the thinking and experiencing thing that I am. Yet, the human agent is capable of such a capacity, natively, and can move through time with ease. While there is not a material object or part that can conceivably make sense of the human agents' conscious mental states, it becomes more significant to recognize that human beings gain and lose parts through the process of time while remaining the self-same persons without those physical objects. This supposition finds support in a premise of faith. As articulated above, Christians are traditionally committed to the doctrine of an intermediate disembodied state in which humans experience reality. In this way, human beings are essentially immaterial substances that bear, at least, one essential immaterial or mental property-namely, the property that I am a conscious experiencing self. 
As a consciously thinking and experiencing self that exists among other consciously thinking selves, we believe that we have a paradigm case for thinking about agents in general, including God, as we suggested above. God, so the tradition holds, is himself an immaterial being and not a material being (Aquinas 2012: 28, Augustine 1994: 65). The foundation for our 'seeing', 'experiencing', or 'knowing' God, then seems naturally to correspond to our immaterial natures as souls in relation to God, who himself is an immaterial being. God has no body nor need for a body. He is without material, which makes sense of the traditional belief that he is immutable without change (Augustine 1994: 88, Lombard 2007: 46).

However, it is true that in our present and normal experience of God we do so as embodied beings. Our embodiment is important in two ways. First, and arguably, it is necessary to the normal process of sense perception. During most of our lives as humans, we live as embodied beings, and we gain access to the physical world in and through the use of our bodies. Bodies provide for humans additional powers that contribute to our knowledge of the world. Second, it is necessary to the full functioning or ordering of human nature. When we have some part of our bodies malfunctioning, then we seem to experience a malfunction in our whole being. When I experience a blow to the head, my states of awareness are dramatically affected (Swinburne 1997: 10, 104, 235, Swinburne 2001: 154). If this is the case, then it follows that bodies provide some sort of operational powers that not only positively affect the souls of human beings, but also situate those souls in a context where it can function properly.

The philosophical data above gives us some reason to think that the traditional impulse is correct with respect to the priority given to the immaterial in the beatific vision. This is in part because of who God is and the fact that we will exist and experience disembodied states--pointing to the essentiality of the immateriality of our nature. Furthermore, even in our embodied experiences, there is a logical and, seemingly, metaphysical priority given to the immaterial, given the data from our having the causal power to sustain a thought from one moment to the next and our ability to endure through time. The first-person perspective, which is distinct from the material realm, is what makes our encounter of the world unified and sustains our reflection across time (Taliaferro 2010). Our point is merely that the traditional impulse is correct, aside from any difficulties that might arise regarding the body.

\section{Additional Development in the Reformed Tradition}

Given the descriptions of Reformed theology and the philosophical arguments above, we believe that the impulse towards the immaterial and intellectual in the beatific vision is well-founded and helpful. Given the priority 
of the immaterial in both God and humans, it makes sense that the vision is also primarily immaterial in nature. While we find the impulse of the Reformed theologians helpful, we do not believe that they have sufficiently developed a holistic (i.e., with a vision of the embodied soul) theology of the beatific vision.

While we have, in this article, already argued that the Reformed tradition correctly maintained that the beatific vision was fundamentally immaterial, now it remains to show that this tradition is in need of some additional development to give proper weight to the final, glorified material existence of the person and its corresponding Christological aspects. To do so, we turn to John Owen and, especially, Jonathan Edwards. Given the shortness of space and our present objectives, we will lay out some of the constructive potential that these theologians afford the contemporary theologian for the purpose of taking these points up in more extensive directions at a later date.

We sense at least two challenges in the Reformed account, challenges that will need further parsing and nuance. First, they (excluding Calvin, Owen, and Edwards) have little to say about the role of Christ, specifically, and the role of the Trinity, more generally, in the beatific vision. Of course, we are not denying that they were Christocentric (especially in their soteriologies), but their accounts of the beatific vision minimize and even ignore, at times, the place of Christ in the vision. Their accounts tend towards an understanding of the anthropological nature of the vision alone. When they do mention God, they give credence to the oneness of God-and not his triunity. One might even say that Turretin's discussion, to mention one example, is devoid of the Trinity and the Christological aspects altogether.

Second, and more central to this contribution, while the Reformed theologians correctly note that the vision lends a priority towards the immaterial, they, we believe, improperly neglect or minimize the glorified resurrected state and its role and/or relation to the vision. As noted, they have little to say about the body's role in the vision; and when they do speak about the body, it is unclear how the body and soul jointly cooperate in the vision itself. As shown above, some of them had a clear place for the vision in the disembodied intermediate state (e.g., see Turretin following Aquinas). Others spoke somewhat confusingly about the vision as both disembodied and occurring in the physically resurrected state.

While Calvin brings some clarity to the discussion where other Reformed theologians are perplexingly unclear, he is less than fully clear on the nature of the immaterial in relation to the material and its implications for the vision. We are not sure if he, and the later tradition, knows how to coherently tie together the immaterial vision with the resurrected state. We are not even sure that they are aware of the tension between the two. For the 
Reformed tradition, the body, unfortunately, becomes deeply perplexing. What we have shown is that this impulse in the Reformed tradition is theologically and philosophically motivated, but it runs into a problem of what to do with the body. Fortunately, John Owen and Jonathan Edwards provide us with some constructive potential for thinking about the vision in relation to the final resurrected state.

Owen has some significant similarities to the Reformed theologians listed earlier, but he also significantly departs from those who are Thomistically motivated (e.g., Francis Turretin). Interestingly, in keeping with his tradition, Owen highlights that the vision is primarily immaterial, but the way he does so is strikingly different. He does not describe the vision in the context of the disembodied intermediate state. Instead, he situates the vision in the resurrected state, which is the first unique contribution. Second, he moves in the material direction when he describes the vision as a vision of the fleshly humanity of Christ (Edwards 1957-2006: 8.720). He took Jesus's words as programmatic for the vision: 'Whoever has seen me has seen the Father' (John 14: 9). Thus, he suggests that the vision entails a direct, physical sight of the glorified Jesus while we are in our glorified bodily state: 'There will be use herein of our bodily eyes... That corporeal sense shall not be restored unto us, and that glorified above what we can conceive but for this great use of the eternal beholding of Christ and his glory' (Owen 1850: 1.379).

This is no generic gaze, but it is a gaze directed at the person of Christ as fully God and fully human. Indeed, the vision involves 'a continual contemplation of the glory of Christ' (Owen 1850: 1.277). Since 'the glory of Christ is the glory of the person of Christ,' he suggests that this vision is of the hypostatically united Jesus Christ as fully God and human (Owen 1850: 1.293; see also McDonald 2015: 146-47). In this sense, the gaze is both intellectual and physical (i.e., sight). This is a rather unique departure from the Reformed tradition before him. Suzanne McDonald argues that the intellectual has priority here (McDonald 2015: 156-157), but Owen does not fall under the same criticisms of the other Reformed theologians mentioned here for two reasons: he has some role for the body in the vision and the immaterial/intellectual vision coincides with the first-person experience of the physically embodied Christ. Yet, it seems that for Owen the only way that the glorified human person can apprehend the divinity of Christ (through a physical gaze of the human person) is through a redeemed and perfected intellect; so even Owen prioritizes the immaterial and does so in the embodied context. However, he does not offer a sufficient accounting or story for the link between the experience of the vision and the bodily glorified state. 
In our assessment, Jonathan Edwards has even more to say both about the Christological nature (i.e., divine-human) in the vision and the relationship of the glorified body to the vision. As noted earlier, it is clear in many texts that Edwards follows the Reformed impulse that the beatific vision is immaterial and intellectual in nature without significant development concerning an embodied vision. However, this is not entirely accurate. When one considers Edwards's extraordinary sermon on Romans 2: 10, he is clear both that (1) Christ is central and mediates the vision of the Father (and the Trinity) and (2) the physical body has a significant role to play in the vision.

To the first, we suggest that, based on Edwards's sermon, Edwards is thoroughly Christological in his development of the vision. He begins by expounding on the nature of humans as encountering God, through a kind of intellectual or spiritual (i.e., immaterial) seeing via Christ. Christ, from beginning to end for Edwards, is central to the soteriological means or mechanism by which humans come to see and apprehend the Father. Indeed, it is in the context of our union to Christ that we have union with God, become children of God, are justified before God, and receive all the divine qualities in Christ. In other words, it is in virtue of our union with Christ that we are able to 'apprehend' the nature of God (Edwards 1995: 889-890). Christ, the divine-human, is the root by which we as soul images are grafted and bear fruit, and this is primarily an act where Christ is "instamped' on the soul of humans (Edwards 1995: 889). Edwards is clear that such a state is immaterial:

Though it be but small, yet it is powerful; it has influence over the heart to govern it, and brings forth holy fruits in the life, and will not cease to prevail till it has consumed all the corruption that is left in the heart, and till it has turned the whole soul into a pure, holy, and heavenly flame, till the soul of man becomes like the angels, a flame of fire, and shines as the brightness of the firmament (Edwards 1995: 889).

The priority of the soul here is apparent. Yet, it is the embodied Christ that mediates to human souls this new perception of God, for Edwards describes Christ-and not simply the Logos-in the present 'earthly' and embodied state of humans. Saying this, Edwards elsewhere makes explicit that the embodied Christ is the medium by which the saints come to have an intellectual vision of God (Edwards 1995: 892).

While the immaterial/intellectual is the primary ontological component in the vision, Edwards assigns a role not only for the body but also specifically the newly bodily resurrected Christ. In his usual fashion, Edwards uses several images signifying that we are seeing God via the embodied Christ during the disembodied state of the saints. Indeed, in one place, Edwards is relatively explicit that it is the resurrected Christ that mediates such a vi- 
sion; namely, in the context of talking about human souls ascending to heaven and obtaining a vision of God, Edwards states this clearly:

There are some who say that there is no such place as heaven; but this is evidently a mistake, for the heaven into which the man Christ Jesus entered with his glorified body, is certainly some place. It is absurd to suppose that the heaven where the body of Christ is, is not a place. To say that the body of Christ is in no place, is the same thing as to say he has no body. The heaven where Christ is, is a place; for he was seen ascending, and will be seen descending again; and the heaven where the departed souls of the saints are, is the same heaven where Christ has ascended. And therefore Stephen, when he was departing this life, saw heaven opened, and the Son of man standing on the right hand of God. And he prayed to that same Jesus whom he saw, that he would receive his spirit; i.e. that he would receive it to him, where he saw him, at the right hand of God... Therefore, there is some place, where God gloriously manifests himself, and where Christ is, and where saints and angels dwell, and whither the angels carry the souls of the saints when they depart from their bodies; and this place is called Paradise, and the third heaven. 2 Cor. xii. 2, 4 (Edwards 1995: 893).

Edwards makes it clear that not only is God immaterial and the vision is intellectual, but that heaven is also a place. For in the fact that Christ, in his embodiment, takes us to God, it is precisely the humanity of Christ in his newly resurrected state that effectuates the disembodied vision for the saints. There is a tendency today to think of the disembodied intermediate state as a diminished state of existence (Witherington 1995: 391, Wright 2003: 216 and 312-74), but this is clearly not the case for Edwards. Edwards's understanding of the disembodied souls is an encounter with the embodied Christ. Edwards describes this state as 'a state of exceeding glory and blessedness' (Edwards 1995: 894). We would be right to point out that Edwards, at this juncture, exceeds Owen when offering a robust accounting for the relationship between the beatific vision in anticipation of the final state of the physical resurrection, but he does not conclude there.

Edwards also has some constructive comments on the disembodied vision in relation to the re-embodied vision. Edwards makes what seems to amount to two claims regarding the relationship between the two states. First, Edwards claims that humans are normally and naturally embodied. In other words, human beings, while fundamentally or essentially soul beings, function as integrally whole beings when embodied. To give just one example, Edwards points us to the embodied Christ, as we show below. Second, Edwards claims that there is a higher or more intense state we as humans enter into when we envision God as newly embodied beings. He describes this state as a more complete and blessed state. In fact, he uses the words of 'exceeding joy' (Edwards 1995: 894). Christ remains the medium by which saints experience the Trinitarian God (Edwards 1995: 894). It is with Christ, 
in his human form, that we ascend, but it is also with Christ that descend back to the earth as resurrected saints (Edwards 1995: 894).

Toward the end of the sermon, Edwards advances some beautifully complex and somewhat perplexing statements about the interaction between bodily seeing and intellectual seeing. Edwards describes the final state as one of seeing God in Christ, as in the disembodied state, yet with 'exceeding strength' and 'wonderful beauty' (Edwards 1995: 894-95). Edwards offers links between the material and the immaterial when he brings the embodied Christ into the discussion.

In this way, John Owen and Jonathan Edwards offer hope as a way forward. They provide some resources for making sense of the 'vision' in the context of the relationship between the intellectual and the physical.

\section{Conclusion}

The Reformed impulse emphasizes the immaterial nature of the beatific vision. Despite the challenges of linking the immaterial vision with the body and the physical resurrection, the theological and philosophical reasons given above seem to root this traditional tendency in a solid and sure footing. Saying this, we recognize the challenge that ensues from such a conclusion. As exemplified in the articulations of the Reformed tradition, it becomes conceptually difficult to link the beatific vision with the physical resurrection of the body and the corresponding Christological elements, yet Owen and Edwards provide a link between the immaterial vision and the final state of humankind in the resurrected state.

Several questions immediately emerge upon reflection. Which state is central and how? It is not entirely clear where the emphasis should lie: in the vision of God or the physical resurrection. More importantly for this article, what is the link between the beatific vision and the resurrected body, or an embodied state more generally? Once again, it is not entirely clear. Is it that the vision itself is enhanced in some way by the resurrected body? These and other related questions impress themselves on those identifying with the medieval and Reformed traditions.

While we believe that the contemporary trajectory toward materialism is unhelpful, we are confronted with the need to offer some thoughtful explanation between the immaterial vision and the resurrection state. Some ideas from John Owen, which remain in seed form at present, may hold out some promise to constructively develop a satisfying account of the relationship between the soul's vision of God and the newly resurrected body. To a greater extent, we find in one sermon by Edwards a more nuanced and theologically complex understanding of the vision that, while commensurate with the Reformed tradition, has some contemporary constructive value. We have merely retrieved, in a modestly constructive fashion, from the 
tradition for the purpose of demonstrating the impulse, offering some justification for it, and, finally, developing some ways forward with the help of Owen and Edwards. Additional work is required to offer an account for the causal or metaphysical relationship between the disembodied state and the state of somatic resurrection, but this must wait for another day.

\section{Bibliography}

Aquinas T (2012) Summa Theologiae. Lander, WY: The Aquinas Institute. Suppl. IIIae. 93, a. 1-3. Available at https://www.ccel.org/ccel/aquinas/summa.XP_Q92_A1.html.

Augustine (1994) On the Trinity, NPNF volume 3. Grand Rapids, MI: Eerdmans.

Bynum C (1995) Why All the Fuss about the Body? A Medievalist's Perspective. Critical Inquiry 22(*): 1-33.

Calvin J (1960) Institutes of the Christian Religion, McNeill JT (ed), Battles FL (trans) [The Library of Christian Classics]. Louisville, KY: Westminster John Knox.

Coakley S (2000) The Eschatological Body. Gender, Transformation, and God. Modern Theology 16(1): 61-73.

Corcoran K (2006) Rethinking Human Nature. A Christian Materialist Alternative to the Soul. Grand Rapids, MI: Baker Academic.

Eagleton T (1996) The Illusions of Postmodernism. Oxford: Blackwell Publishers.

Edwards J (1957-2006) The Works of Jonathan Edwards in 26 volumes. Miller P, Smith JE, and Stout HS (eds) New Haven, CT: Yale University Press.

Edwards J (1995) Sermons. The Works of Jonathan Edwards, volume 2, Hickman E (ed) Philadelphia, PA: The Banner of Truth Trust.

Farris J. (2014) Discovering God and Soul. A Reappraisal of and Appreciation for Cartesian Natural Theology. Philosophia Christi 16(1): 37-57.

Hasker W (2001) The Emergent Self. Ithaca, NY: Cornell University Press.

Helm P (2010) Calvin at the Centre. Oxford: Oxford University Press.

Helm P (2004) John Calvin's Ideas. Oxford: Oxford University Press.

Hodge C (2003) Systematic Theology. Peabody, MA: Hendrickson.

Hoekema A (1994) The Bible and the Future, second edition. Grand Rapids, MI: Eerdmans.

Kwan K (2011) The Rainbow of Experiences, Critical Trust, and God. A Defense of Holistic Empiricism. London: Bloomsbury.

Lombard P (2007) The Sentences. Book 1, The Mystery of the Trinity, Silano G (trans) Toronto: Pontifical Institute of Mediaeval Studies.

Lund D (2003) Making Sense of It All. An Introduction to Philosophical Inquiry, second edition. New Jersey, NJ: Prentice Hall. 
McDonald S (2015) Beholding the Glory of God in the Face of Jesus Christ. John Owen and the 'Reforming' of the Beatific Vision. The Ashgate Research Companion to John Owen's Theology, Kapic KM, Mark J (eds) Burlington, VT: Ashgate.

Murphy N (2006) Bodies and Souls, or Spirited Bodies? Cambridge: Cambridge University Press.

Owen J (1850-1855) Meditations and Discourses on the Glory of Christ in his Person, Office, and Grace. In The Works of John Owen, Gould WH (ed), 24 volumes. London: Johnstone and Hunter.

Rosemann PW (2004) Peter Lombard [Great Medieval Thinkers] Davies B (ed) Oxford: Oxford University Press.

Smith TL (2003) Thomas Aquinas' Trinitarian Theology. A Study in Theological Method. Washington, DC: The Catholic University of America Press.

Sullivan J (2016 [1907]) The Athanasian Creed. The Catholic Encyclopedia, volume 2. New York, NY: Robert Appleton Company, 1907. Accessed 20 August 2016 on http://www.newadvent.org/cathen/02033b.htm [cited on August 20, 2016].

Swinburne R (1994) The Christian God. Oxford: Oxford University Press.

Swinburne R (1997) The Evolution of the Soul. Oxford: Oxford University Press.

Taliaferro C (2010) The Soul of the Matter. The Soul Hypothesis: Investigations into the Existence of the Soul. New York, NY: Bloomsbury.

***** (2013) Seemings and Justification: New Essays on Dogmatism and Phenomenal Conservatism. Tucker C (ed) Oxford: Oxford University Press.

Turretin F (1997) Institutes of Elenctic Theology, Musgrave Giger G (trans), Dennison JT (ed) Phillipsburg, NJ: P \& R.

Wilhelm J (2016 [1911]) The Nicene Creed. The Catholic Encyclopedia, volume 11. New York, NY: Robert Appleton Company. Accessed 20 August 2016 on http://www.newadvent.org/cathen/11049a.htm [cited on August 20, 2016].

Witherington III B (1995) Conflict and Community in Corinth. A SocioRhetorical Commentary on 1 and 2 Corinthians. Grand Rapids, MI: Eerdmans.

Wright NT (2008) Surprised by Hope. Rethinking Heaven, the Resurrection, and the Mission of the Church. New York, NY: Harper One. 